\title{
Microbial Aspects of Accelerated Degradation of Metam Sodium in Soil
}

\author{
Shachaf Triky-Dotan, Maya Ofek, Miriam Austerweil, Bracha Steiner, Dror Minz, Jaacov Katan, and Abraham Gamliel
}

First, third, fourth, and seventh authors: Laboratory for Pest Management Research, Institute of Agricultural Engineering, and second and fifth authors: Institute of Soil, Water and Environmental Sciences, ARO, The Volcani Center, P.O. Box 6, Bet Dagan 50250, Israel; first, second, and sixth authors: Department of Plant Pathology and Microbiology, The Hebrew University of Jerusalem, the Robert H. Smith Faculty of Agriculture, Food and Environment, Rehovot 76100, Israel.

Accepted for publication 4 December 2009.

\begin{abstract}
Triky-Dotan, S., Ofek, M., Austerweil, M., Steiner, B., Minz, D., Katan, J., and Gamliel, A. 2010. Microbial aspects of accelerated degradation of metam sodium in soil. Phytopathology 100:367-375.

Preplant soil fumigation with metam sodium is used worldwide to control soilborne diseases. The development of accelerated degradation of pesticides in soil, including metam sodium, results in reduced pesticide efficacy. Therefore, we studied microbial involvement in accelerated degradation of methyl isothiocyanate (MITC) following repeated soil applications of the parent compound, metam sodium. MITC degradation was reduced in soil with a history of metam sodium applications following sterilization, indicating the key role of microorganisms in accelerated degradation. Accelerated degradation of MITC was induced by inoculation of soil with no previous application of metam sodium with soil with a history of metam sodium applications. We developed a method to extract the active microbial fraction responsible for MITC degradation from soil with a history of metam sodium applications. This concentrated

different soils with no previous application of metam sodium. An extensive shift in total bacterial community composition in concentrated soil extracts occurred after a single metam sodium application. Two Oxalobacteraceae strains, MDB3 and MDB10, isolated from Rehovot soil following triple application of metam sodium rapidly degraded MITC in soil with no previous application of metam sodium. Polymerase chain reaction-denaturing gradient gel electrophoresis analysis of bacterial community composition showed relative enrichment of MDB3 following metam sodium application, suggesting its potential in situ involvement in accelerated degradation development in Rehovot soil. Responses of resident Oxalobacteraceae community members to metam sodium applications differed between Rehovot and En Tamar soils. Isolate MDB10 did not induce accelerated degradation of MITC in En Tamar soil and, with the slow dissipation of MITC, soil suppressiveness of accelerated degradation is suggested. The isolation and identification of MITC-degrading bacteria might be helpful in developing tools for managing accelerated degradation.
\end{abstract} soil extract induced accelerated degradation of MITC when added to two
Accelerated degradation of a pesticide in soil occurs when its active ingredient undergoes rapid decomposition, thereby reducing its pesticidal activity $(19,30,31,43,50)$. Accelerated degradation is usually associated with repeated applications but, with certain pesticides, it may even develop following a single application $(30,31,35,36)$. Accelerated degradation was first reported with the herbicide 2,4-dichlorophenoxyacetic acid (2,4-D) (6) and it is a well-known phenomenon with commonly used pesticides. However, in recent years, it has also been reported for the soil fumigant metam sodium $(15,20,40,46,48,50)$.

Metam sodium (sodium $N$-methyl dithiocarbamate) is frequently used for the control of soilborne pests in fields. In moist soils, metam sodium rapidly undergoes decomposition to its active ingredient, methyl isothiocyanate (MITC), which is then distributed in the vapor and liquid phases of the soil. MITC is toxic to soilborne pests, particularly fungi, and to some soil arthropods, ectoparasitic nematodes, and weeds (22,39). Generation and dissipation of MITC in the soil follows first-order degradation kinetics and is controlled by microbial and physicochemical processes $(11,21,22,38,41,51)$. The process has been shown to vary among different soils (46).

Repeated applications of metam sodium in controlled systems has been reported to result in accelerated degradation of MITC

Corresponding author: A. Gamliel; E-mail address: agamliel@agri.gov.il

doi:10.1094/PHYTO-100-4-0367

(C) 2010 The American Phytopathological Society and loss of biocidal activity $(15,40,42,48,50)$. Recently, we reported the occurrence of accelerated degradation of MITC in soil under commercial field conditions as well, following repeated applications of metam sodium (46). Accelerated degradation of MITC can be induced by the application of different MITC precursors, including synthetic chemicals such as dazomet (15) or plant debris (52).

Accelerated degradation of a soil fumigant or any pesticide may result from the enrichment of indigenous microbial degraders of the pesticide in the soil, increased enzymatic activity of the degraders, the transfer of extrachromosomal elements of the degraders to other components of the soil microbial community, or a combination of these factors $(2,30,31,36)$. Studies have indicated that, in sterilized soil, degradation of MITC is slower than in nonsterilized soil, suggesting that biological degradation is the major factor in MITC degradation $(16,27$, 51,54,55). The microorganisms (mainly bacteria) which have been found to degrade various soil fumigants have been listed in several reviews $(5,17)$. Warton et al. (51) isolated heatresistant Rhodococcus and Bacillus spp. from soil exhibiting accelerated degradation which may be involved in the accelerated degradation of MITC. Ibkwe et al. $(26,27)$ found a wider diversity of bacteria associated with the degradation of MITC and 1,3dichloropropene (1,3-D) following amendment with composted manure.

In contrast to many reports on accelerated degradation of various pesticides, only a few studies have looked at this phenomenon with soil fumigants such as metam sodium. Therefore, the 
objectives of the present study were to (i) assess the microbial mechanisms involved in the development of accelerated degradation of MITC, (ii) isolate and identify microorganisms that degrade MITC in soil with accelerated degradation, and (iii) examine the consequences of repeated applications of metam sodium on the composition of the soil bacterial community.

\section{MATERIALS AND METHODS}

Soils. Two sandy soils were used in this study. The first, a soil from Rehovot in the central part of Israel, had clay, silt, and sand content of 4, 2, and 94\%, respectively; organic matter at $1.0 \mathrm{~g} \mathrm{~kg}^{-1}$; $\mathrm{pH} 7.9$, as determined in a 1:1 (wt/wt) water extract; and a field capacity (measured at $-0.033 \mathrm{MPa}$ external pressure) of $9 \%$. The second soil was collected from Zohar experimental station in En Tamar in the northern Arava desert valley and had clay, silt, and sand content of 4,7 , and $89 \%$, respectively; organic matter at $1.4 \mathrm{~g} \mathrm{~kg}^{-1} ; \mathrm{pH} 8.1$, as determined in a $1: 1(\mathrm{wt} / \mathrm{wt})$ water extract; and a field capacity (measured at $-0.033 \mathrm{MPa}$ external pressure) of $8 \%$. Neither soil had a history of metam sodium application for at least 5 years prior to sampling. All samples were collected from the fields from the upper soil layer ( 5 to $20 \mathrm{~cm}$ in depth). Five subsamples of soil (total of $20 \mathrm{~kg}$ ) were mixed into one large composite sample, air dried, and sieved through a 2-mm screen. The soils were then stored in plastic containers at room temperature until use (up to 3 weeks after collection).

Culture medium. Modified MITC agar medium (51) was used in all experiments. The medium contained (per liter of distilled water) $20 \mathrm{~g}$ of agar, $1 \mathrm{ml}$ of MITC (1 g dissolved in $10 \mathrm{ml}$ of absolute ethanol), $3 \mathrm{~g}$ of yeast extract, and mineral salts $\left(\mathrm{NaNO}_{3}\right.$, $2 \mathrm{~g} ; \mathrm{K}_{2} \mathrm{HPO}_{4}, 1 \mathrm{~g} ; \mathrm{KH}_{2} \mathrm{PO}_{4}, 0.5 \mathrm{~g} ; \mathrm{NaCl}, 0.1 \mathrm{~g} ; \mathrm{MgSO}_{4} \cdot 7 \mathrm{H}_{2} \mathrm{O}$, $0.5 \mathrm{~g} ; \mathrm{CaCl}_{2}, 0.01 \mathrm{~g}$; and $\mathrm{FeSO}_{4} \cdot 7 \mathrm{H}_{2} \mathrm{O}, 0.01 \mathrm{~g}$ ). The same medium without agar was used for liquid culture.

Inducing accelerated degradation of MITC in soil. This procedure was performed in fumigation containers as previously described $(15,45,46)$. We prepared an aqueous solution of metam sodium (Edigan 37\% a.i.; Makhtechim-Agan Chemicals, Ashdod, Israel) which was incorporated into the soil at a rate of $60 \mu \mathrm{g} \mathrm{g}^{-1}$ of dry soil. The solution was added to each container with an equivalent volume of water to achieve $80 \%$ of the water-holding capacity of the treated soil. The containers were incubated at $25^{\circ} \mathrm{C}$ for 7 days, and then the containers were opened and aerated for an additional 7 days. Metam sodium applications were repeated through this sequence three times, after which the soil was considered a "history-soil". This soil was compared for MITC degradation with soil which did not received previous application of metam sodium and which was first applied during the experiment ("nonhistory-soil"). Soil containers with application of the same volume of tap water only served as nontreated controls ("nontreated-soil").

Assessment of MITC generation and dissipation in the soils. MITC generation and dissipation curves were recorded in fumigation containers as previously described $(15,45,46)$. MITC concentration in the container headspace was assayed by solidphase microextraction (SPME) and gas chromatography (GC) as previously described $(7,15)$. The lower detection limit of MITC using this method was $0.65 \mathrm{ng} \mathrm{cm}^{-3}$. Concentration-time $(\mathrm{C} \times \mathrm{T})$ products of MITC (expressed as micrograms per hour per cubic centimeter) were calculated as the area under the MITC generation-dissipation curve over time $(15,18,45)$. The integration was calculated numerically according to the trapezoidal rule (49).

Viability assays. Fusarium oxysporum f. sp. radicis-lycopersici was used as the assay organism for viability testing. In previous laboratory studies, we found that $F$. oxysporum f. sp. radicislycopersici is a reliable bioassay organism for testing metam sodium application $(15,45,46)$. Inoculum, consisting of chlamydospores in naturally infested soil in nylon net bags, was buried in each set of containers before metam sodium application. The net bags with fungal resting structures were retrieved and assayed for viability of $F$. oxysporum f. sp. radicis-lycopersici propagules following metam sodium treatment by soil-dilution-plating technique $(15,18)$. Each of three 2.5 -g soil subsamples from each replicate was added to $22.5 \mathrm{ml}$ of sterile water agar $(0.1 \% \mathrm{wt} / \mathrm{vol})$ containing $\mathrm{MgSO}_{4} \cdot 7 \mathrm{H}_{2} \mathrm{O}(0.1 \% \mathrm{wt} / \mathrm{vol})$. The samples were shaken for 1 min with a bag mixer (BagMixer 400; Interscience, St. Nom-La-Breteche, France) at 8 strokes $\mathrm{s}^{-1}$, then serially diluted with the same solution. Aliquots of $0.2 \mathrm{ml}$ from each dilution were spread onto the agar surface of each of four petri dishes that contained a modified peptone-pentachloronitrobenzene selective agar medium (15). The plates were incubated in the dark at $28^{\circ} \mathrm{C}$ for 4 to 6 days. Randomly selected colonies of $F$. oxysporum isolates that originated from the soil were tested for pathogenicity on tomato transplants, to verify their identity as $F$. oxysporum f. sp. radicis-lycopersici (18). The results are expressed as CFU per gram of soil that had been dried at $105^{\circ} \mathrm{C}$ for $48 \mathrm{~h}$. The percent mortality was calculated by comparison with the population in the nontreated containers.

Soil sterilization. Soil samples (1 kg of soil with volume of water to achieve $80 \%$ of the water-holding capacity) were sterilized prior to treatment by autoclaving twice at $121^{\circ} \mathrm{C}(100 \mathrm{kPa})$ for $1 \mathrm{~h}$ each time at a $24-\mathrm{h}$ interval. Samples of the sterilized soil were checked for sterility by soil-dilution-plating technique $(15,18)$ as previously described, and were all found to be free of culturable microbes.

Increasing density of microbial degraders of MITC in soil. We developed a method to extract and concentrate the soil population of microbial degraders of MITC in a small volume of water. A 1-kg sample of soil was saturated with $380 \mathrm{ml}$ of tap water for $12 \mathrm{~h}$. Then, the soil paste was filtered through a 325-mesh screen and the filtrate was centrifuged $(5,000 \mathrm{rpm}$ for $10 \mathrm{~min})$. The supernatant was removed, leaving a pellet containing water and fine solid particles in a total volume of $20 \mathrm{ml}$, equivalent to $2.53 \mathrm{~g}$ of dry material. Thus, $1 \mathrm{ml}$ of concentrated soil extract originated from $50 \mathrm{~g}$ of the original tested soil. The concentrated soil extract was mixed with water (to a maximal volume of $12.5 \mathrm{ml}$ ) and then applied to the soil containers. The degradation capacity of MITC in the concentrated soil extract was tested in soil containers as already described and MITC concentration in the vapor phase was assessed.

Assessment of MITC in the liquid phase. The capacity of soil extract to degrade MITC was also assessed in the liquid phase. Soil extract was spiked into $250-\mathrm{ml}$ flasks containing $50 \mathrm{ml}$ of liquid culture medium with MITC (described above). The flasks were shaken in a reciprocal shaker $\left(150\right.$ strokes $\left.\mathrm{min}^{-1}\right)$ and incubated at $25^{\circ} \mathrm{C}$ for 7 days. MITC was periodically assessed using the SPME-GC procedure described above. Additional treatments, including MITC medium without soil extract or bacteria, served as controls.

Isolation of MITC-degrading bacteria from soil and assessment of their activity. Soil samples $(2.5 \mathrm{~g})$ from Rehovot soil following triple application of metam sodium were added to $22.5 \mathrm{ml}$ of sterile water agar $(0.1 \% \mathrm{wt} / \mathrm{vol})$ containing $\mathrm{MgSO}_{4}$. $7 \mathrm{H}_{2} \mathrm{O}(0.1 \% \mathrm{wt} / \mathrm{vol})$. The samples were shaken for $1 \mathrm{~min}$ with a bag mixer (BagMixer 400; Interscience) at 8 strokes s ${ }^{-1}$, and then serially diluted with the same $\mathrm{MgSO}_{4}$ solution. Aliquots of $0.1 \mathrm{ml}$ from each dilution were spread onto the agar surface of each of four petri dishes that contained the modified MITC agar medium and incubated in the dark at $28^{\circ} \mathrm{C}$ for 2 weeks, and isolates were obtained. The ability of 12 isolated strains to degrade MITC was tested in sterilized soil. For each isolate, a 3-day-old culture from MITC agar was harvested and suspended in sterile distilled water ( $3 \mathrm{ml}$ plate $^{-1}$ ). Each suspension was then mixed with $250 \mathrm{~g}$ of sterilized soil in a container to achieve $10^{3} \mathrm{CFU} \mathrm{g}^{-1}$ of soil. The containers with this soil were incubated at $25^{\circ} \mathrm{C}$ for 3 days; then, metam sodium was added and MITC concentration in the soil was followed according to the procedure described above. 
Identification of bacterial isolates and phylogenetic analyses. Products of a nearly full-length $16 \mathrm{~S}$ ribosomal (r)RNA gene (primer set 3, described below) obtained from the two strains were isolated from Rehovot soil following three repeated applications of metam sodium and were sequenced using ABI PRISM (Applied Biosystems, Foster City, CA) sequencing technology (Macrogen, Seoul, South Korea). Recovered sequences were submitted to the National Center for Biotechnology Information (NCBI) for BLAST analysis (4). Further analyses of the $16 \mathrm{~S}$ rRNA gene sequences were performed using the program package ARB (33). Sequences were aligned to the ARB gene database with the ARB automated alignment tool and refined manually by visual inspection and secondary-structure analysis. A neighborjoining tree was produced. Phylogenetic affiliation of the isolated bacterial sequences was determined according to both ARB and NCBI-BLAST results. The sequences determined in this study were deposited in the GenBank database under accession numbers FJ911521 and FJ911522 (for MITC-degrading bacteria [MDB]3 and MDB10, respectively). Based on sequence, the two isolates were closely related and showed similar MITC-degradation performance. Therefore, we focused on isolate MDB10, which was easier to maintain in pure culture and exhibited higher rates of MITC degradation. In addition, MDB10 was identified by the fatty acid profile (conducted at the analytical laboratory of the Plant Protection Inspection Services of the Volcani Center, Bet Dagan, Israel).

DNA extraction. DNA was extracted from soil samples of nontreated soil and soils following single or three repeated applications of metam sodium using a modified bead-beating method (28). Briefly, crude extracts were initially recovered from samples via bead beating (Fast Prep FP 120, Bio101; Savant Instruments Inc., Holbrook, NY) in extraction buffer $(100 \mathrm{mM}$ Tris $\mathrm{HCl}, \mathrm{pH} 8.0 ; 100 \mathrm{mM}$ potassium phosphate buffer, $\mathrm{pH} 8.0$; $1 \%$ [wt/vol] cetyltrimethylammonium bromide; and $2 \%$ [wt/vol] sodium dodecyl sulfate). The crude extracts were mixed with $\mathrm{KCl}$ to a final concentration of $0.5 \mathrm{M}$, incubated for $5 \mathrm{~min}$, and centrifuged. DNA present in the supernatant was bound to glassmilk (0.5- to $10-\mu \mathrm{m}$ silica particles) (Sigma-Aldrich, St. Louis) with $\mathrm{NaI}$ as described elsewhere (12). The glassmilk was washed with an ethanol-based wash buffer solution (12). After removal of liquid residues by centrifugation, DNA bound to the silica was eluted with $80 \mu \mathrm{l}$ of $10 \mathrm{mM}$ Tris-EDTA, $\mathrm{pH} 8.0$ (Amresco Inc., Solon, $\mathrm{OH}$ ), into a sterile tube and stored at $-20^{\circ} \mathrm{C}$ prior to use.

Polymerase chain reaction amplification. Portions of the $16 \mathrm{~S}$ rRNA genes were amplified from extracted DNA samples using three primer sets: (i) the universal primer-set 341-F, containing a GC clamp (required for downstream denaturing gradient gel electrophoresis [DGGE] application), and 907-R (23); (ii) the Oxalobacteraceae-specific primer pair OX225-F and OX1249-R (24); and (iii) primers 11-F and 1392-R for isolated bacteria (14). A nested polymerase chain reaction (PCR) approach was used for DGGE analysis of Oxalobacteraceae as described by Green et al. (24). PCR products obtained with primer set 2 were diluted 1:50 and $1 \mu \mathrm{l}$ of the diluted product was used as a template for PCR using primer set 1 , enabling a comparison of the band patterns of total bacterial community and Oxalobacteraceae populations.

The PCR mixture contained $1.5 \mathrm{U}$ of Taq DNA polymerase (RedTaq; Sigma-Aldrich), $1.25 \mu \mathrm{M}$ each primer, $4 \mathrm{mM} \mathrm{MgCl}_{2}$, $1 \mathrm{mM}$ dNTP mix, $6.25 \mathrm{ng}$ of bovine serum albumen, and $1 \mu \mathrm{lof}$ DNA in a final volume of $50 \mu \mathrm{l}$. All reactions were conducted in a Tgradient Thermocycler (Whatman Biometra, Goettingen, Germany) according to the following protocols. For set no. 1, PCR mixes were initially denatured for $3 \mathrm{~min}$ at $95^{\circ} \mathrm{C}$ and then cycled 35 times through three steps: denaturation $\left(30 \mathrm{~s}\right.$ at $\left.94^{\circ} \mathrm{C}\right)$, annealing $\left(30 \mathrm{~s}\right.$ at $\left.56^{\circ} \mathrm{C}\right)$, and elongation $\left(30 \mathrm{~s}\right.$ at $\left.72^{\circ} \mathrm{C}\right)$. For set no. 2 , PCR mixes were initially denatured for $3 \mathrm{~min}$ at $95^{\circ} \mathrm{C}$ and then cycled 35 times through three steps: denaturation $\left(30 \mathrm{~s}\right.$ at $\left.94^{\circ} \mathrm{C}\right)$, annealing $\left(30 \mathrm{~s}\right.$ at $\left.57^{\circ} \mathrm{C}\right)$, and elongation $\left(30 \mathrm{~s}\right.$ at $\left.72^{\circ} \mathrm{C}\right)$. For set no. 3, PCR mixes were initially denatured for $3 \mathrm{~min}$ at $95^{\circ} \mathrm{C}$ and then cycled 35 times through three steps: denaturation $(30 \mathrm{~s}$ at $\left.94^{\circ} \mathrm{C}\right)$, annealing $\left(30 \mathrm{~s}\right.$ at $\left.60^{\circ} \mathrm{C}\right)$, and elongation $\left(75 \mathrm{~s}\right.$ at $\left.72^{\circ} \mathrm{C}\right)$. A 2-min incubation at $72^{\circ} \mathrm{C}$ was added to the end of each PCR program. All amplification products were checked for size and yield by $1.5 \%$ agarose gel electrophoresis.

DGGE analysis of $16 \mathrm{~S}$ rRNA gene fragments, amplified by PCR, was conducted in order to compare the compositions of bacterial communities of nontreated soil and soils following single or three repeated applications of metam sodium. DGGE was performed in $6 \%$ (wt/vol) acrylamide gels containing a linear urea-formamide gradient of 20 to $70 \%$ denaturant (with $100 \%$ defined as $7 \mathrm{M}$ urea and $40 \%$ [vol/vol] formamide). Gels were run for $17 \mathrm{~h}$ at $100 \mathrm{~V}$ with the Dcode Universal Mutation System (Bio-Rad Laboratories, Hercules, CA). DNA was visualized after staining with Gelstar (Invitrogen Corporation, Carlsbad, CA) by UV transillumination $(302 \mathrm{~nm})$ and was photographed with a Kodak KDS digital camera (Kodak Co., New Haven, CT).

Clustering analysis of DGGE profiles. DGGE patterns were aligned and analyzed using Fingerprint II software (Bio-Rad Laboratories). A neighbor-joining tree based on Pearson $r$ distance matrix was produced. Aligned densitometric curves were exported from the Fingerprint II software and multidimensional scaling analysis was performed based on 1-Pearson $r$ distance matrix using STATISTICA (version 7.1) software (Stat Soft Inc., Tulsa, OK).

Statistical analyses. All experiments were carried out at least twice. Data of F. oxysporum f. sp. radicis-lycopersici mortality, which were taken as percentages, were arcsine transformed before analysis. The effects of history of metam sodium application and soil treatment were tested by two-way analysis of variance. The combinations were compared by one-way analysis of variance and interaction effects were tested by contrast $t$ tests. All treatment means were compared simultaneously by the Fisher protected test for significant differences. All analyses were performed with the SAS program (release8.01 for PC; SAS Inst., Cary, NC) at $P \leq 0.05$.

\section{RESULTS}

Degradation of MITC in soils. In soil with a history of metam sodium applications, MITC concentration was reduced to undetectable amounts within $26 \mathrm{~h}$ whereas, in soil with no previous application of metam sodium, more than 13 days were required (Fig. 1), confirming the development of accelerated degradation as found previously $(15,16,27,46)$. Sterilization of soil with a history of metam sodium applications nullified accelerated degradation of MITC. The $\mathrm{C}_{\mathrm{MITC}} \times \mathrm{T}$ products in sterilized soil with a history of metam sodium applications were similar to that in sterilized soil with no previous application of metam sodium (18.4 and $18.3 \mu \mathrm{g} \mathrm{h} \mathrm{cm}^{-3}$, respectively), indicating the involvement of microorganisms in the degradation of MITC.

Mixing of soil with a history of metam sodium applications (at $20 \%$, wt $/ \mathrm{wt}$ ) with soil with no previous application of metam sodium induced accelerated degradation of MITC in the soil mixture (Fig. 2). $\mathrm{C}_{\text {MITC }} \times \mathrm{T}$ products were significantly reduced, by $60 \%$, in the soil mixture compared with soil with no previous application of metam sodium $\left(4.8\right.$ and $12.4 \mu \mathrm{g} \mathrm{h} \mathrm{cm}{ }^{-3}$, respectively). However, F. oxysporum f. sp. radicis-lycopersici mortality in this soil mixture was not significantly affected compared with soil with no previous application of metam sodium (82 and $100 \%$, respectively). Pathogen mortality in soil with previous metam sodium applications was zero. Accelerated degradation of MITC was shown in soil with a history of metam sodium applications by indication of $\mathrm{C}_{\mathrm{MITC}} \times \mathrm{T}$ values and $F$. oxysporum $\mathrm{f}$. sp. radicislycopersici mortality (2.2 and $0 \%$, respectively). Mixing of soil with a history of metam sodium applications (at 10\%, wt/wt) with 
soil with no previous application of metam sodium did not have any significant effect on MITC degradation or on $F$. oxysporum $\mathrm{f}$. sp. radicis-lycopersici mortality.

Degradation of MITC by concentrated soil extracts. The degrading capacity of the concentrated soil extract from soil with a history of metam sodium applications was assessed by mixing this extract in increasing amounts with soil with no previous application of metam sodium. Even a small amount of concentrated soil extract ( $1 \mathrm{ml}$ of concentrated soil extract with $250 \mathrm{~g}$ of soil with no previous application of metam sodium) resulted in a $54 \%$ reduction in $\mathrm{C}_{\mathrm{MITC}} \times \mathrm{T}$ products compared with soil with no previous application of metam sodium (Fig. 3). At higher rates of concentrated soil extract mixed with soil with no previous application of metam sodium, MITC degradation was enhanced and was similar to that in soil with a history of metam sodium applications.

Incorporating the concentrated soil extract of Rehovot soil with a history of metam sodium applications into another soil, En Tamar, also induced accelerated degradation of MITC to a level

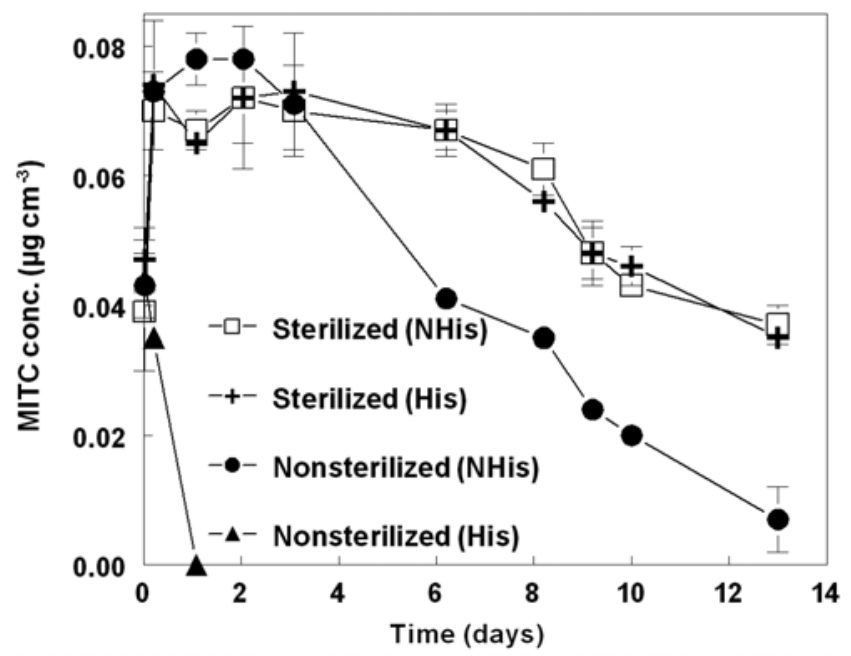

Fig. 1. Effect of soil sterilization on generation and dissipation of methyl isothiocyanate (MITC) in Rehovot soil with a history of metam sodium applications (His) and in Rehovot soil with no previous application of metam sodium (NHis). Soil was sterilized prior to treatment by autoclaving twice at $121^{\circ} \mathrm{C}(100 \mathrm{kPa})$ for $1 \mathrm{~h}$ each time, at a 24 -h interval. Vertical bars indicate \pm standard deviation.

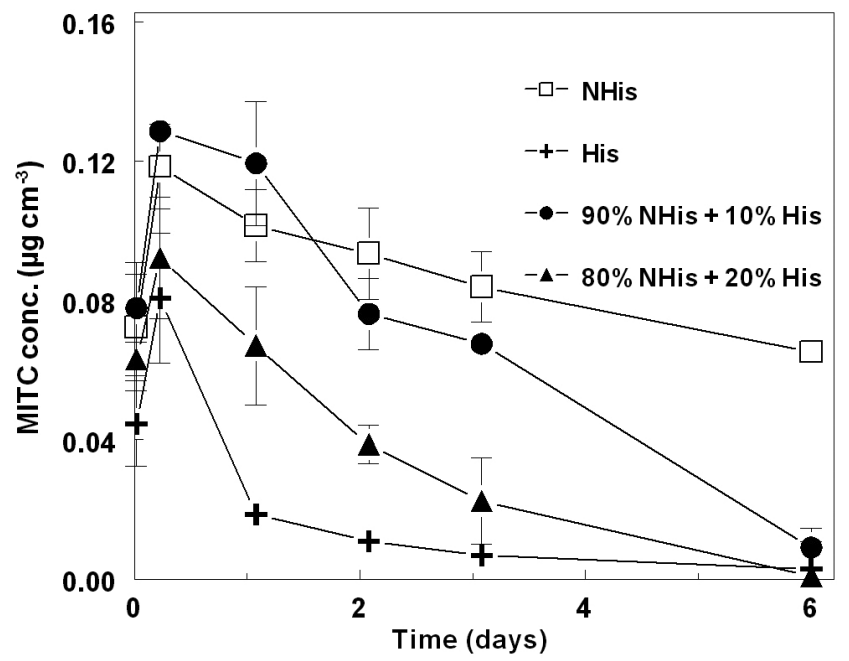

Fig. 2. Effect of mixing Rehovot soil with a history of metam sodium applications (His) with Rehovot soil with no previous application of metam sodium (NHis) on generation and dissipation of methyl isothiocyanate (MITC). Vertical bars indicate \pm standard deviation. similar to the accelerated degradation in Rehovot soil with a history of metam sodium applications $\left(\mathrm{C}_{\text {MITC }} \times \mathrm{T}\right.$ products $=0.7$ and $0.3 \mu \mathrm{g} \mathrm{h} \mathrm{cm}^{-3}$, respectively) (Fig. 4). Thus, the accelerated degradation agents were transmissible and efficient, even in a foreign soil.

The degrading capacity of concentrated soil extract originating from soil with a history of metam sodium applications was also assessed in liquid medium containing MITC. A significant accelerated degradation of MITC was observed when concentrated soil extract originating from soil with a history of metam sodium applications was added to MITC liquid medium (Table 1). In contrast, accelerated degradation of MITC was not observed when similar amounts of concentrated soil extract originating from soil with no previous application of metam sodium or when the original soils were applied. Sterilization of the concentrated

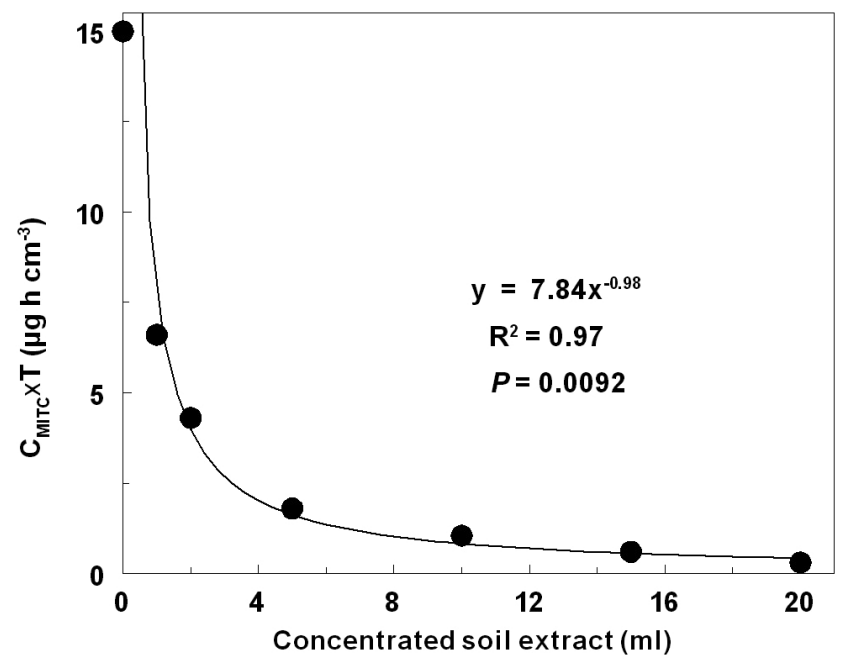

Fig. 3. Effect of adding concentrated soil extract of Rehovot soil with a history of metam sodium applications to Rehovot soil with no previous application of metam sodium $(250 \mathrm{~g})$ on the concentration-time $\left(\mathrm{C}_{\text {MITC }} \times \mathrm{T}\right)$ products of methyl isothiocyanate (MITC). Values of $\mathrm{C}_{\text {MITC }} \times \mathrm{T}$ were calculated from the area under the generation-dissipation curve for each soil mixture $(144 \mathrm{~h})$. Samples of $1 \mathrm{ml}$ of concentrated soil extract originated from $50 \mathrm{~g}$ of original soil.

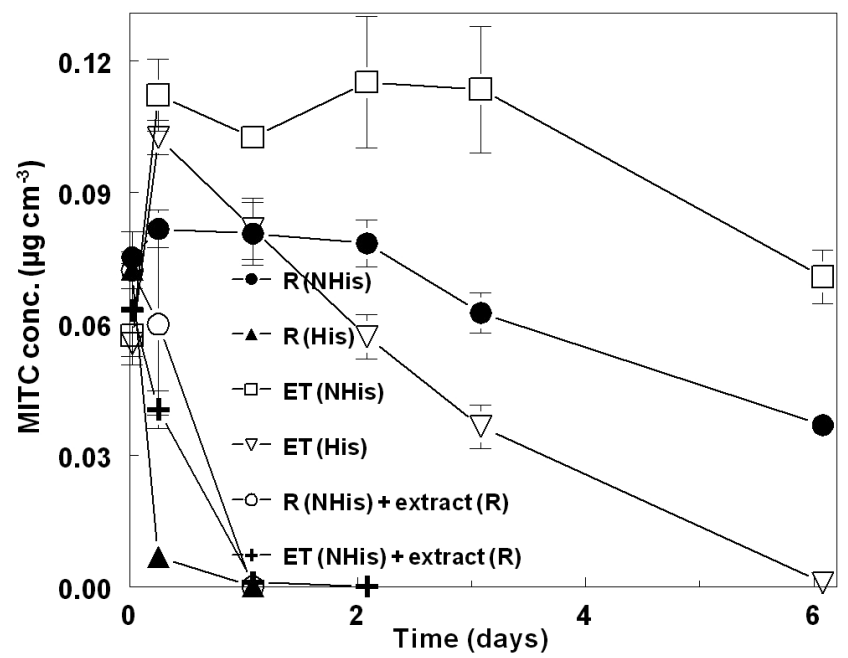

Fig. 4. Effect of concentrated soil extract of soil with a history of metam sodium applications (His) added to soil with no previous application of metam sodium (NHis) on generation and dissipation of methyl isothiocyanate (MITC) in Rehovot (R) or En Tamar (ET) soils. Samples of $8 \mathrm{ml}$ of concentrated soil extract, originating from $400 \mathrm{~g}$ of original soil with a history of metam sodium applications, were added to $250 \mathrm{~g}$ of soil with no previous application of metam sodium. Vertical bars indicate \pm standard deviation. 
soil extract in liquid medium, before MITC application, nullified MITC degradation (Table 1). Heating of the concentrated soil extract from soil with a history of metam sodium applications in liquid medium to $60^{\circ} \mathrm{C}$ for $2 \mathrm{~h}$ before MITC application partially reduced accelerated degradation of MITC (Table 1).

Isolation of MITC-degrading bacteria from soil. Out of 12 bacteria which were isolated from Rehovot soil with a history of metam sodium applications, 2 induced accelerated degradation of MITC when inoculated at concentrations of $10^{3} \mathrm{CFU} \mathrm{\textrm {g } ^ { - 1 }}$ of sterilized Rehovot soil with no previous application of metam sodium (Fig. 5). Rapid MITC degradation in sterilized soil, with no previous application of metam sodium, was achieved by inoculation of isolates MDB10 and MDB3: MITC became below detection limits within 6 and 24 h, respectively. According to NCBI-BLAST and ARB analysis of 16S rRNA gene sequences, the MDB isolates were closely related phylogenetically to each other. The two isolates also showed similar MITCdegradation performance. In addition, accelerated degradation of MITC occurred in sterilized soil, with no previous application of metam sodium, inoculated with isolate MDB10 at the higher metam sodium concentration of $360 \mu \mathrm{l} \mathrm{g}^{-1}$ of soil or in liquid medium which contained MITC at $360 \mu \mathrm{ml}^{-1}$ (data not shown).

The effect of inoculation of isolate MDB10 on the development of accelerated degradation of MITC was compared between Rehovot and En Tamar soils. Inoculation of either sterilized or nonsterilized Rehovot soil, with no previous application of metam sodium, with isolate MDB10 resulted in significant accelerated degradation of MITC, similar to the accelerated degradation in

TABLE 1. Effect of concentrated soil extract (experiment A), sterilization (experiment B), and heating (experiment C) on methyl isothiocyanate (MITC) concentration-time products $\left(\mathrm{C}_{\mathrm{MITC}} \times \mathrm{T}\right)$ following MITC application in a liquid medium ${ }^{\mathrm{x}}$

\begin{tabular}{llr}
\hline Experiment, soil & \multicolumn{1}{c}{ Treatment } & $\mathrm{C}_{\mathrm{MITC}} \times \mathrm{T}(\mu \mathrm{g} \mathrm{h} \mathrm{cm})^{-3}$ \\
\hline A & & \\
Nonhistory & Extract & $24,028 \mathrm{Aa}$ \\
History & Extract & $1,296 \mathrm{Bb}$ \\
Nonhistory & Soil & $24,388 \mathrm{Aa}$ \\
History & Soil & $24,289 \mathrm{Aa}$ \\
B & & \\
Nonhistory & Extract & $26,678 \mathrm{Aa}$ \\
History & Extract & $6,858 \mathrm{Bb}$ \\
Nonhistory & Extract, sterilized & $23,751 \mathrm{Aa}$ \\
History & Extract, sterilized & $25,990 \mathrm{Aa}$ \\
C & & \\
Nonhistory & Extract & $43,266 \mathrm{Aa}$ \\
History & Extract & $3,098 \mathrm{Bb}$ \\
Nonhistory & Extract, $60^{\circ} \mathrm{C}$ & $45,688 \mathrm{Aa}$ \\
History & Extract, $60^{\circ} \mathrm{C}$ & $28,550 \mathrm{Ab}$ \\
\hline
\end{tabular}

${ }^{\mathrm{x}}$ Liquid medium $(50 \mathrm{ml})$ was inoculated with soil $(1 \mathrm{~g})$ or with concentrated soil extract ( $8 \mathrm{ml}$ originating from $400 \mathrm{~g}$ of original soil). In experiment $\mathrm{B}$, samples of concentrated soil extract (from nonhistory or history-soil) in liquid medium were sterilized prior to treatment by autoclaving twice at $121^{\circ} \mathrm{C}(100 \mathrm{kPa})$ for $1 \mathrm{~h}$ each time at a $24-\mathrm{h}$ interval. In experiment $\mathrm{C}$, samples of concentrated soil extract in liquid medium were heated $\left(60^{\circ} \mathrm{C}\right.$ for $2 \mathrm{~h})$ prior to treatment.

y Soil samples were treated by single (nonhistory) or triple (history) applications of metam sodium $\left(60 \mu \mathrm{g} \mathrm{g}^{-1}\right.$ of soil) under controlled conditions in the laboratory.

${ }^{\mathrm{z}}$ MITC concentration was measured periodically during the fumigation process under controlled conditions in a laboratory. A dissipation concentration curve was drawn for each treatment. $\mathrm{C}_{\mathrm{MITC}} \times \mathrm{T}$ values were calculated by integrating the area under the dissipation curve for each treatment for $144 \mathrm{~h}$ of incubation (experiments $\mathrm{A}$ and $\mathrm{B}$ ) or $168 \mathrm{~h}$ of incubation (experiment C). Within each experiment, uppercase letters denote differences among treatments within each soil; lowercase letters denote differences among soils for each treatment according to Tukey's multiple range test. Statistical analysis of $\mathrm{C}_{\mathrm{MITC}} \times \mathrm{T}$ values shows a significant interaction for each experiment $(F=214.7, P \leq 0.0001 ; F=74.7, P \leq 0.0001$; and $F=39.8$, $P \leq 0.0002$, respectively) among the main effects.
Rehovot soil with a history of metam sodium application $\left(\mathrm{C}_{\text {MITC }} \times \mathrm{T}\right.$ products $=0.02,0.3$, and $0.5 \mu \mathrm{g} \mathrm{h} \mathrm{cm}{ }^{-3}$, respectively $)$ (Fig. 6). However, isolate MDB10 did not induce accelerated degradation of MITC in nonsterilized En Tamar soil with no previous application of metam sodium. A significant reduction of $61 \%$ in $\mathrm{C}_{\mathrm{MITC}} \times \mathrm{T}$ products occurred following inoculation with isolate MDB10 in sterilized En Tamar soil compared with the respective noninoculated soil $\left(4.2\right.$ and $10.8 \mu \mathrm{g} \mathrm{h} \mathrm{cm}^{-3}$, respectively).

Identification and characterization of MDB3 and MDB10. According to $16 \mathrm{~S}$ rRNA gene sequences, both isolates were phylogenetically related to members of the Oxalobacteraceae family (Fig. 7). MDB3 was most closely related ( $>97 \%$ sequence similarity) to Massilia timonae (GenBank accession no. AJ871463) while MDB10 was most closely related (>99\%

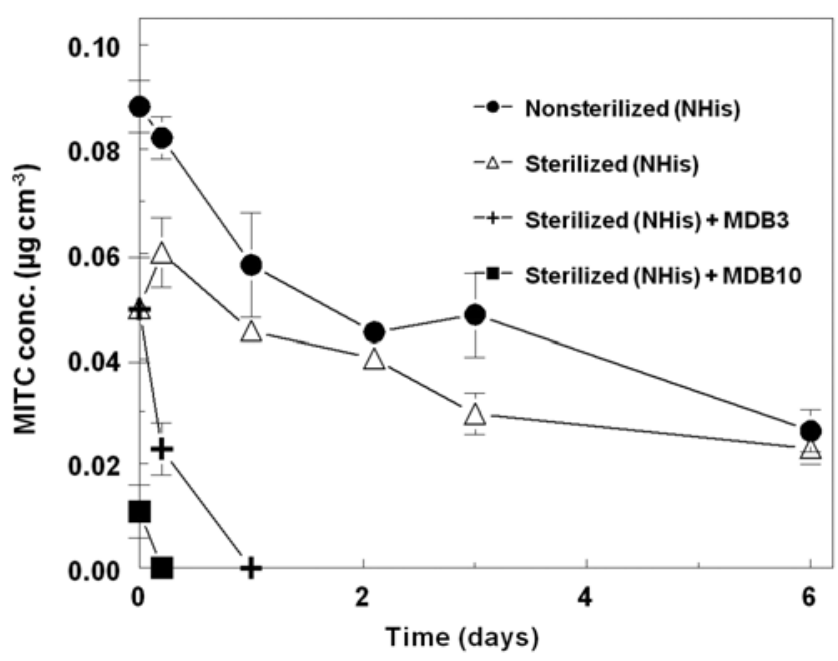

Fig. 5. Effect of inoculation of Rehovot soil with no previous application of metam sodium (NHis) with methyl isothiocyanate-degrading bacteria (MDB3 and MDB10) on generation and dissipation of methyl isothiocyanate (MITC) with and without soil sterilization. Soils were sterilized prior to treatment by autoclaving at twice $121^{\circ} \mathrm{C}(100 \mathrm{kPa})$ for $1 \mathrm{~h}$ each time, at a $24-\mathrm{h}$ interval. For each isolate, culture suspension was mixed with sterilized soil (250 $\mathrm{g}$ for each replicate) in a container to achieve $10^{3} \mathrm{CFU} \mathrm{g}^{-1}$ of soil. Vertical bars indicate \pm standard deviation.

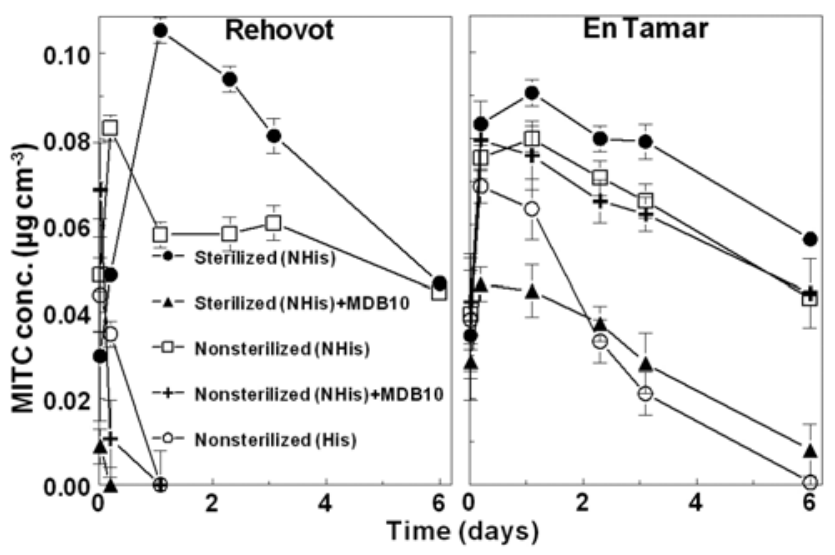

Fig. 6. Effect of inoculation of soil with no previous application of metam sodium (NHis) with methyl isothiocyanate-degrading bacterial isolate (MDB10) on generation and dissipation of methyl isothiocyanate (MITC) in Rehovot and En Tamar soils. Soil with a history of metam sodium applications (His) served as a reference. Soils were sterilized prior to treatment by autoclaving at twice $121^{\circ} \mathrm{C}(100 \mathrm{kPa})$ for $1 \mathrm{~h}$ each time, at a 24-h interval. Culture suspension was mixed with sterilized soil ( $250 \mathrm{~g}$ for each replicate) in a container to achieve $10^{3} \mathrm{CFU} \mathrm{g}^{-1}$ of soil. Vertical bars indicate \pm standard deviation. 
sequence similarity) to Naxibacter sp. X16-7 (GenBank accession no. EU073130). Fatty acid analysis of isolate MDB10 gave the following pattern: $\mathrm{C}_{(16: 1)} \omega 7 \mathrm{c}(47.38 \%), \mathrm{C}_{(16: 0)}(22.98 \%), \mathrm{C}_{(18: 1)} \omega 7 \mathrm{c}$ (11.78\%), $\mathrm{C}_{(10: 0)} 3-\mathrm{OH}$ (7.31\%), $\mathrm{C}_{(12: 0)}(5.13 \%), \mathrm{C}_{(12: 0)} 2-\mathrm{OH}$ $(3.39 \%), \mathrm{C}_{(14: 0)}(0.74 \%), \mathrm{C}_{(10: 0)}(0.64 \%)$, and $\mathrm{C}_{(17: 1)} \omega 9 \mathrm{c}(0.64 \%)$. According to Kampfer et al. (29), the presence of the major fatty acids $\mathrm{C}_{(16: 1)} \omega 7 \mathrm{c}$ and $\mathrm{C}_{(16: 0)}$ with $\mathrm{C}_{(10: 0)} 3-\mathrm{OH}$ and $\mathrm{C}_{(12: 0)} 2-\mathrm{OH}$ as hydroxylated fatty acids supports the affiliation of the isolates to the genus Naxibacter of the Oxalobacteraceae.

PCR-DGGE analysis performed on total DNA extracted directly from the soils was used to assess the relative dominance of the isolates within the soil bacterial communities (Fig. 8). In nontreated soil, bands representing MDB3 and MDB10 could not be detected. Following application of metam sodium, relative abundance of MDB3 had increased. This was indicated by the appearance of bands in the community DGGE patterns of the first and third application of metam sodium soils at the same migration distance as the one representing this isolate. However, no such indication could be obtained for isolate MDB10.

Effect of MITC on soil community composition of bacteria and Oxalobacteraceae. Bacterial community composition in treated and nontreated soils was examined by PCR-DGGE analysis performed on total DNA extracted directly from the soils (Fig. 9). Because the two isolates belonged to Oxalobacteraceae, the composition of this family was also examined using a nestedPCR approach. PCR-DGGE patterns were analyzed using both hierarchical cluster analysis (Fig. 9A and B) and multidimensional scaling analysis (Fig. 9C and D). The two analytical methods gave complementary results. A major shift in soil bacterial community composition could be observed in both Rehovot and En Tamar soils after a single application of metam sodium. Further application of metam sodium caused a few additional changes in bacterial community composition (Fig. 9). In both soils, the number of dominant bands was lower in metam sodiumtreated samples than in nontreated ones. In addition, most of the dominant bands in the treated samples were also present in the patterns of the nontreated soils.

Metam sodium application resulted in strong shifts in Oxalobacteraceae composition in both Rehovot and En Tamar soils, although the type of shift differed between the two soils. In Rehovot soil, the main effect of metam sodium applications was the addition of a dominant Oxalobacteraceae population, following the first metam sodium application (Fig. 9A and D). Oxalobacteraceae population dominated, lasting through the third metam sodium application. By contrast, in En Tamar soil, the main effect of metam sodium application on Oxalobacteraceae composition was observed only after the third metam sodium application (Fig. 9B and D).

\section{DISCUSSION}

Our study showed that accelerated degradation of MITC as also reflected in pathogen mortality, similar to previous studies $(15,46)$, may develop following repeated applications of metam sodium due to the enhanced activity of naturally occurring microbial MITC degraders in the soil. Moreover, we isolated and identified two bacteria which were able to rapidly degrade MITC in Rehovot soil. Metam sodium application to the soil resulted in a major shift in the composition of bacterial communities. However, for specific bacterial groups, namely the Oxalobacteraceae, repeated application of metam sodium was required to induce a shift in composition in the En Tamar soil.

The soil microbial constituent determines MITC degradation $(16,27)$. The crucial role played by microorganisms in MITC degradation was verified in this study, as also was shown by Warton et al. (51). Indeed, the nullification of MITC degradation in sterilized soil with a history of metam sodium applications constitutes additional support for microbial-mediated development of accelerated degradation in soil. We also showed induction of accelerated degradation by mixing soil with a history of metam sodium applications $(20 \%$, wt/wt) with soil with no previous application of metam sodium, similar to Di Primo et al. (15). These results led us to assess whether the microbial constituents

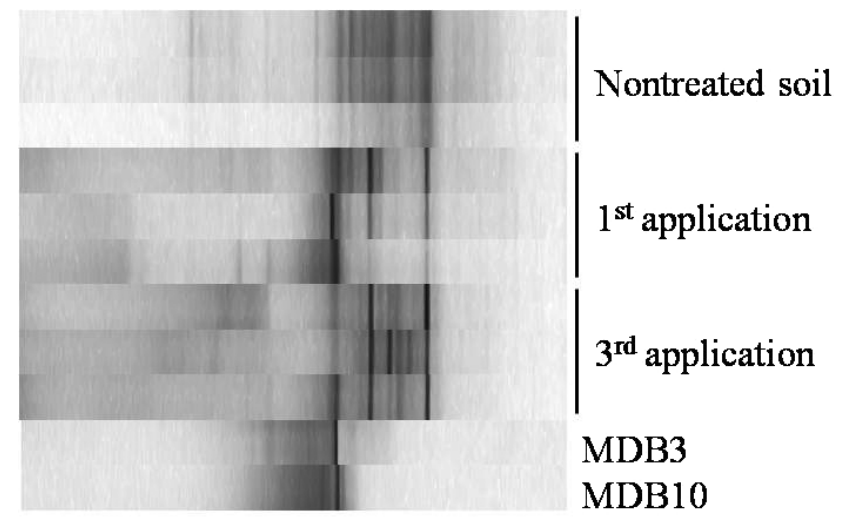

Fig. 8. Representation of methyl isothiocyanate-degrading bacterial (MDB) isolates within the dominant bacterial populations in Rehovot soil following repeated applications of metam sodium. 16S ribosomal RNA gene fragments obtained from isolates MDB3 and MDB10 were examined by polymerase chain reaction-downstream denaturing gradient gel electrophoresis (PCRDGGE) in relation to the PCR-DGGE patterns of Rehovot soil bacterial communities in nontreated soil and soils following single or three repeated applications of metam sodium (three replicates for each treatment). Patterns were aligned and compared using Fingerprint II software.

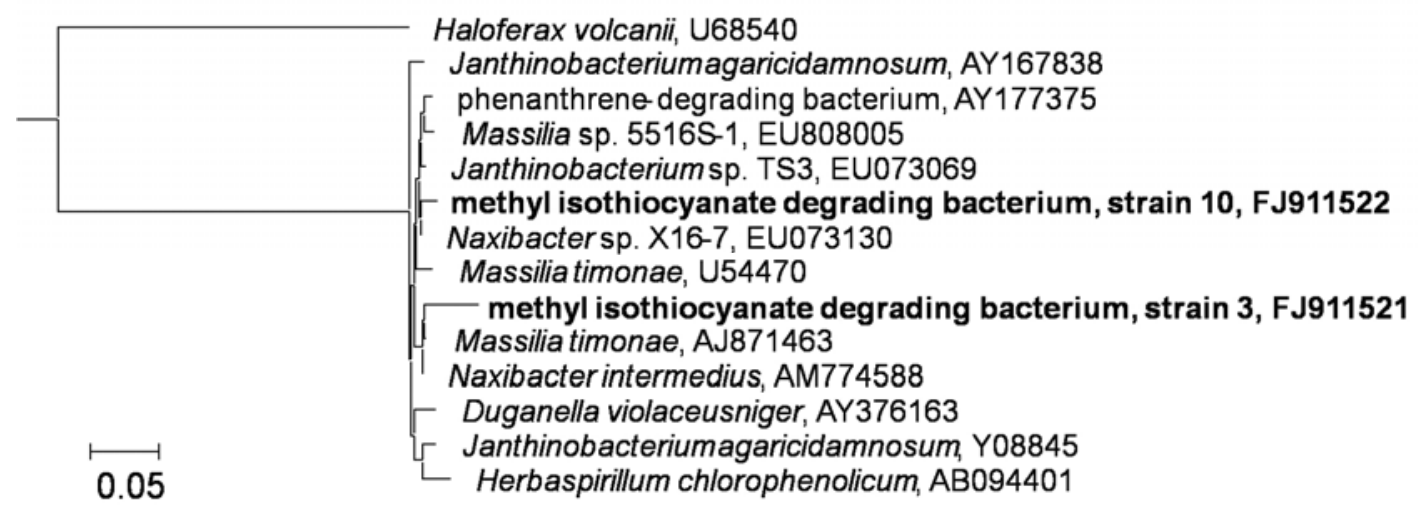

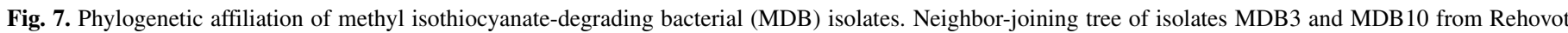

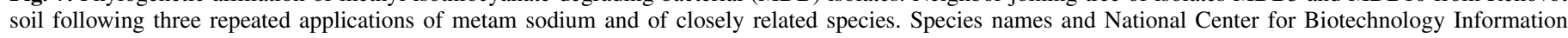
accession numbers are presented. Scale bar indicates an estimated 5\% sequence divergence. 
of Rehovot soil can induce accelerated degradation of MITC in Rehovot soil with no previous application of metam sodium as well as in the less active accelerated-degradation soil from En Tamar. We developed a soil-extraction method for the recovery and concentration of the microbial fraction active in MITC degradation.. The developed method also enabled reproduction of accelerated degradation in culture medium, further emphasizing the role of microbial degraders in accelerated degradation.

The effect of pesticide application on soil bacterial communities has been previously studied, with results ranging from a lack of effect $(9,32)$ to a strong effect $(37,47)$, apparently due to variations in the nature of the different pesticides $(26,32)$ as well as to differences between the experimental systems. Previous studies have reported only a weak though persistent effect of MITC application on soil bacterial community composition (26, 32). A strong effect of metam sodium application on bacterial community composition was observed in this study for the concentrated soil extract of two distinct soils. Moreover, a major shift in composition in the concentrated extract of nontreated soil was already observable after the first metam sodium application in both soils.

Previous identification of potential MITC-degrading bacteria has been achieved mainly through sequence analysis of relevant DNA fragments isolated from bacterial community DGGE patterns (27). Here, we present the isolation of MITC-degrading bacteria in pure culture. Out of 12 bacterial isolates from Rehovot soil with a history of metam sodium applications which were able to grow on MITC agar, 2 strains showed rapid degradation of MITC in soil. The isolate MDB10 was capable of degrading high concentrations of MITC in both liquid culture (data not shown) and soil; therefore, we hypothesized that repeated applications of MITC may serve as a selection factor enhancing the enrichment of their populations in soil. Indeed, for isolate MDB3, this assumption was supported by the results of the PCR-DGGE analysis. The ability to isolate environmentally relevant bacteria tends to be limited (34). Therefore, the findings regarding MDB3 are of particular interest and may indicate the involvement of this population in in situ degradation of MITC. It is highly probable that other groups of organisms are also involved, whether directly or indirectly, in accelerated degradation. Warton et al. (51) showed that soil inoculation with a consortium of bacterial strains able to grow on MITC agar results in accelerated degradation of MITC in sterilized soil. The accelerated degradation ability of these bacteria was not assessed in nonsterilized soil and the individual ability of each strain to induce accelerated degradation of MITC was not examined. In addition, the MITC-degrading isolates were found to be heat resistant (51). In our study, accelerated degradation of MITC was only partially delayed by heating the concentrated soil extract to $60^{\circ} \mathrm{C}$ prior to MITC addition.

Sequence analyses of the 16S rRNA gene of isolates MDB3 and MDB10 revealed their affiliation with members of the Oxalobacteraceae family, which are known soil bacteria (24). Several members of this family have been reported to be involved in the removal of environmental pollutants, including aliphatic, aromatic, and polyaromatic hydrocarbons $(3,10,25)$; however, thus far, not in the degradation of pesticides. PCR-DGGE analysis specific for Oxalobacteraceae revealed a response of this population to metam sodium application which was distinct from that of the general bacterial community. Moreover, response patterns differed between the Rehovot and En Tamar soils. Although the response of the Rehovot soil's total bacterial community to metam sodium application was characterized by the removal of dominant species, the composition of Oxalobacteraceae populations remained relatively stable, with the addition of a highly dominant population. In En Tamar soil, a significant shift in Oxalobacteraceae composition required repeated applications, though a major shift in total bacterial community occurred after a single application.
Like many biotic phenomena, the intensity of accelerated degradation should not be expected to be similar in all soils. Indeed, accelerated degradation was much more pronounced in the Rehovot soil than in the En Tamar soil (46) (Fig. 4). This difference was also reflected in these soils' different responses to inoculation with MDB10 and in their shifts in microbial composition. The effect of MDB10 inoculation into En Tamar soil was restricted to sterilized soil and caused a reduction of the $\mathrm{C}_{\mathrm{MITC}} \times \mathrm{T}$ product but did not induce a pronounced accelerated degradation. These results suggest that both biological and physicochemical characteristics of En Tamar soil contribute to the suppression of MDB10-mediated MITC degradation. It appears that the establishment of this degrading bacterium was easier in Rehovot soil than in En Tamar soil. An analogous phenomenon is soil suppressiveness toward soilborne pathogens (13). Thus, those soils in
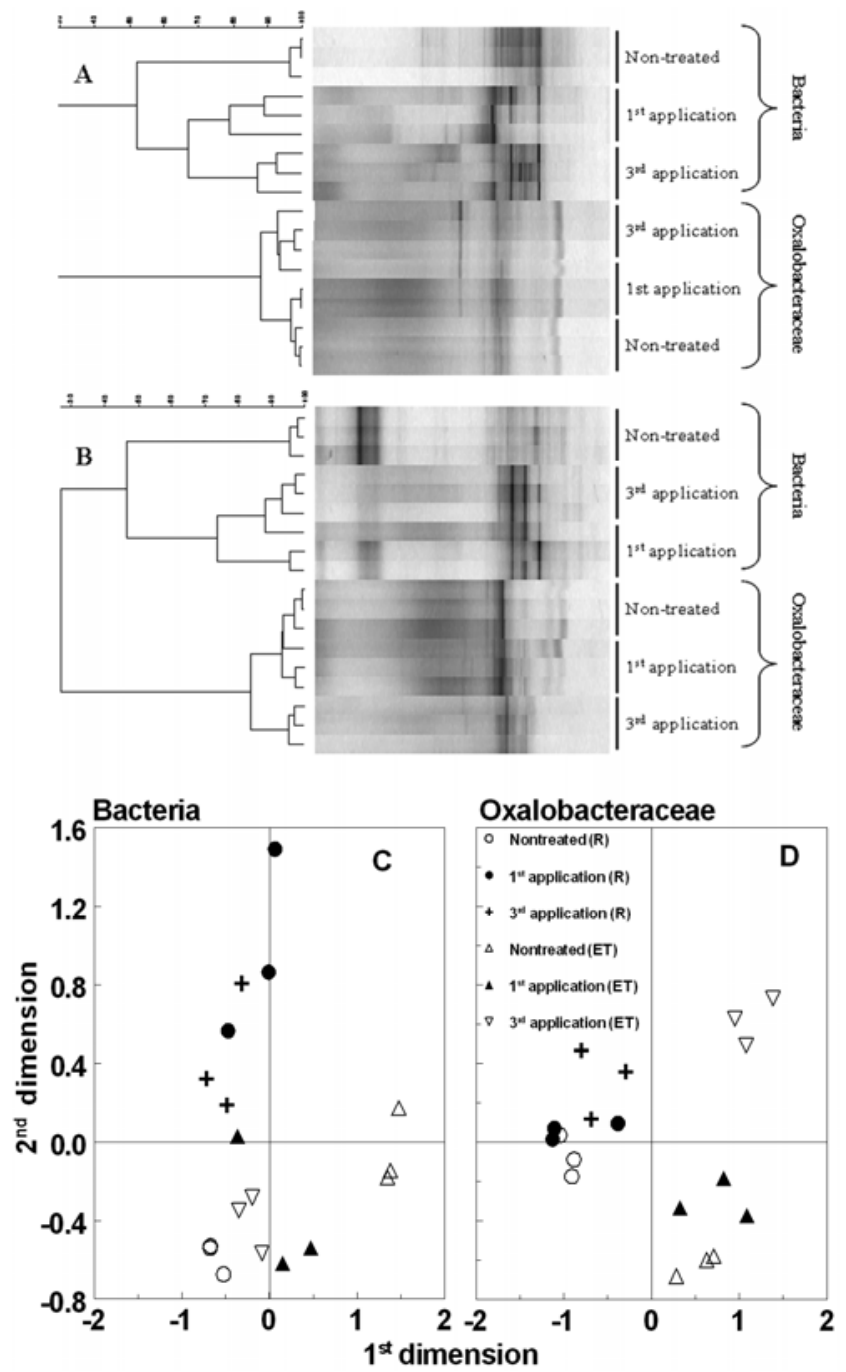

Fig. 9. Effect of three repeated applications of metam sodium on composition of bacterial community and Oxalobacteraceae population in A, Rehovot and B, En Tamar soils. Bacterial community compositions in nontreated soil and soils following single or three repeated applications of metam sodium (three replicates for each treatment) were compared based on polymerase chain reaction-downstream denaturing gradient gel electrophoresis (PCR-DGGE) patterns of $16 \mathrm{~S}$ ribosomal RNA gene fragments using a general bacterial primer pair and an Oxalobacteraceae-specific primer pair. Community patterns were analyzed using Fingerprint II software. A and B, Neighbor-joining tree was calculated from 1-Pearson $r$ correlation distance matrix. C and D, Multidimensional scaling analysis (MDSA) of DGGE pattern densitometric curves (for bacteria and Oxalobacteraceae, respectively) in Rehovot (R) and En Tamar (ET) soils. MDSA was performed based on 1-Pearson $r$ distance matrix between the densitometric curves using STATISTICA software. The first and second dimensions are presented (stress $<0.05$ ). 
which the establishment of a certain pathogen is relatively slower are defined as suppressive compared with conducive soils. Therefore, we regard Rehovot and En Tamar soils as conducive and suppressive to MDB10-mediated accelerated degradation of MITC, respectively. Hence, approaches to pathogen control need to be adopted, with modifications for the management of accelerated degradation (1). Indeed, soil disinfestation and fungicides $(8,44,53)$ slow the accelerated degradation of certain pesticides. Furthermore, reducing the frequency of pesticide application in the same soil should be a major component in the management of accelerated degradation.

\section{ACKNOWLEDGMENTS}

We thank P. Bucki, L. Iasur-Kruh, L. Kautsky, V. Zilberg, M. Beniches, J. Riven, and E. Klein for their technical assistance and MakhtechimAgan for providing the metam sodium for all studies. This research was supported in part by grant no. 459-0354 from the Chief Scientist of the Israeli Ministry of Agriculture and Rural Development. Mention of a proprietary product does not constitute an endorsement or recommendation for use by the Israeli Ministry of Agriculture, nor does it imply the lack of efficacy of similar products not mentioned. Contribution 703/09 series from the Agricultural Research Organization, The Volcani Center, Bet Dagan, Israel.

\section{LITERATURE CITED}

1. Aharonson, N., and Katan, J. 1991. Pesticide behavior in solarized and disinfected soils. Pages 131-138 in: Soil Solarization. J. Katan and J. E. De Vay, eds. CRC Press, Boca Raton, FL.

2. Aislabie, J., and Lloyd-Jones, G. 1995. A review of bacterial degradation of pesticides. Aust. J. Soil Res. 33:925-942.

3. Alfreider, A., and Vogt, C. 2007. Bacterial diversity and aerobic biodegradation potential in a BTEX-contaminated aquifer. Water Air Soil Pollut. 183:415-426.

4. Altschul, S. F., Madden, T. L., Schäffer1, A. A., Zhang, J., Zhang, Z., Miller, W., and Lipman, D. J. 1997. Gapped BLAST and PSI-BLAST: A new generation of protein database search programs. Nucleic Acids Res. 25:3389-3402.

5. Arbeli, Z., and Fuentes, C. L. 2007. Accelerated biodegradation of pesticides: An overview of the phenomenon, its basis and possible solutions; and a discussion on the tropical dimension. Crop Prot. 26:17331746.

6. Audus, L. J. 1949. The biological detoxification of 2,4-dichlorophenoxiacetic acid in soil. Plant Soil 2:31-36.

7. Austerweil, M., Gamliel, A., Di Primo, P., and Steiner, B. 2002. Elucidation of the behavior of fumigants in soil by solid microextraction (SPME) and gas liquid chromatography (GC). Proc. 10th IUPAC Congr. Chem. Crop Prot. Basel, Switzerland, Vol. 2:37

8. Avidov, E., Aharonson, N., Katan, J., Rubin, B., and Yarden, O. 1985. Persistence of terbutryn and atrazine in soil as affected by soil disinfestation and fungicides. Weed Sci. 33:457-461.

9. Bending, G. D., Rodriguez-Cruz, M. S., and Lincoln, S. D. 2007. Fungicide impacts on microbial communities in soils with contrasting management histories. Chemosphere 69:82-88.

10. Bodour, A. A., Wang, J. M., Brusseau, M. L., and Maier, R. M. 2003. Temporal change in culturable phenanthrene degraders in response to long-term exposure to phenanthrene in a soil column system. Environ. Microbiol. 5:888-895.

11. Boesten, J. J. T. I., van der Pas, L. J. T., Smelt, J. H., and Leistra, M. 1991. Transformation rate of methyl isothiocyanate and 1,3-dichloropropene in water-saturated sandy subsoils. Neth. J. Agric. Sci. 39:179190.

12. Boyle, J. S., and Lew, A. M. 1995. An inexpensive alternative to glassmilk for DNA purification. Trends Genet. 11:8.

13. Cook, R. J., and Baker, K. F. 1983. The Nature and Practice of Biological Control of Plant Pathogens. American Phytopathological Society, St. Paul, MN.

14. Cytryn, E., Minz, D., Gieseke, A., and van Rijn, J. 2006. Transient development of filamentous Thiothrix species in a marine sulfide oxidizing, denitrifying fluidized bed reactor. FEMS Microbiol. Lett. 256:22-29.

15. Di Primo, P., Gamliel, A., Austerweil, M., Steiner, B., Beniches, M., Peretz-Alon, I., and Katan, J. 2003. Accelerated degradation of metamsodium and dazomet in soil: Characterization and consequences for pathogen control. Crop Prot. 22:635-646.
16. Dungan, R. S., Gan, J., and Yates, S. R. 2003. Accelerated degradation of methyl isothiocyanate in soil. Water Air Soil Pollut. 142:299-310.

17. Dungan, R. S., and Yates, S. R. 2003. Degradation of fumigant pesticides: 1,3-Dichloropropene, methyl isothiocyanate, chloropicrin and methyl bromide. Vadose Zone J. 2:279-286.

18. Eshel, D., Gamliel, A., Grinstein, A., and Katan, J. 1999. Evaluation of soil fumigants on soilborne fungal pathogens in a controlled-environment system and in soil. Crop Prot. 18:437-443.

19. Felsot, A. S. 1989. Enhanced biodegradation of insecticides in soil: Implications for agroecosystems. Annu. Rev. Entomol. 34:453-476.

20. Gamliel, A., and Triky-Dotan, S. Accelerated degradation of soil fumigants: Occurrence and agricultural consequences. Pages 311-328 in: Recent Developments in Disease Management Series: Plant Pathology in the 21st Century, Vol. 1. M. L., Gullino, U. Gisi, and I. Chet, eds. Springer, The Netherlands.

21. Gan, J., Papiernik, S. K., Yates, S. R., and Jury, W. A. 1999. Temperature and moisture effects on fumigant degradation in soil. J. Environ. Qual. 28:1436-1441.

22. Gerstl, Z., Mingelgrin, U., and Yaron, B. 1977. Behaviour of Vapam and methylisothiocyanate in soils. Soil. Sci. Soc. Am. J. 41:545-548.

23. Green, S. J., Inbar, E., Michel, F. C., Hadar, Y., and Minz, D. 2006. Succession of bacterial communities during early plant development: Transition from seed to root and effect of compost amendment. Appl. Environ. Microbiol. 72:3975-3983.

24. Green, S. J., Michel, F. C., Hadar, Y., and Minz, D. 2007. Contrasting patterns of seed and root colonization by bacteria from the genus Chryseobacterium and from the family Oxalobacteraceae. ISME J. 1:291299.

25. Hamamura, N., Olson, S. H., Ward, D. M., and Inskeep, W. P. 2006. Microbial population dynamics associated with crude-oil biodegradation in diverse soils. Appl. Environ. Microbiol. 72:6316-6324.

26. Ibekwe, A. M., Papiernik, S. K., Gan, J., Yates, S. R., Yang, C. H., and Crowley, D. E. 2001. Impact of fumigants on soil microbial communities. Appl. Environ. Microbiol. 67:3245-3257.

27. Ibekwe, A. M., Papiernik, S. K., and Yang, C. H. 2004. Enrichment and molecular characterization of chloropicrin- and metam-sodium-degrading microbial communities. Appl. Microbiol. Biotechnol. 66:325-332.

28. Inbar, E., Green, S. J., Hadar, Y., and Minz, D. 2005. Competing factors of compost concentration and proximity to root affect the distribution of Streptomycetes. Microb. Ecol. 50:73-81.

29. Kampfer, P., Falsen, E., and Busse, H. J. 2008. Naxibacter varians sp. nov. and Naxibacter haematophilus sp. nov., and emended description of the genus Naxibacter. Int. J. Syst. Evol. Microbiol. 58:1680-1684.

30. Katan, J., and Aharonson, N. 1989. Accelerated degradation of pesticides. Pages 193-207 in: Toxic Organic Chemicals in Porous Media. Z. Gerstl, Y. Chen, U. Mingelgrin, and B. Yaron, eds. Ecological Studies, Vol. 73. Springer-Verlag, Berlin.

31. Kaufman, D. D., Katan, J., Edwards, D. F., and Jordan, E. D. 1985. Microbial adaptation and metabolism of pesticides. Pages 437-451 in: Agricultural Chemicals of the Future. J. L. Hilton, ed. Rowman \& Allanheld Press, NJ.

32. Klose, S., Acosta-Martinez, V., and Ajwa, H. A. 2006. Microbial community composition and enzyme activities in a sandy loam soil after fumigation with methyl bromide or alternative biocides. Soil Biol. Biochem. 38:1243-1254

33. Ludwig, W., Strunk, O., Westram, R., Richter, L., Meier, H., Yadhukumar, Buchner, A., Lai, T., Steppi, S., Jobb, G., Forster, W., Brettske, I., Gerber, S., Ginhart, A. W., Gross, O., Grumann, S., Hermann, S., Jost, R., Konig, A., Liss, T., Lussmann, R., May, M., Nonhoff, B., Reichel, B., Strehlow, R., Stamatakis, A., Stuckmann, N., Vilbig, A., Lenke, M., Ludwig, T., Bode, A., and Schleifer, K. H., 2004. ARB: A software environment for sequence data. Nucleic Acids Res. 32:1363-1371.

34. Ovreas, A., and Torsvik, V. 1998. Microbial diversity and community structure in two different agricultural soil communities. Microb. Ecol. 36:303-315

35. Racke, K. D., and Coats, J. R. 1990. Enhanced biodegradation of pesticides in the environment. ACS Symp. Ser. No. 426. Am. Chem. Soc., Washington, DC.

36. Roeth, F. W. 1986. Enhanced herbicide degradation in soil with repeat application. Rev. Weed Sci. 2:45-65.

37. Ros, M., Goberna, M., Moreno, J. L., Hernández, T., García, C., Insam, H., and Pascual, J. A. 2006. Molecular and physiological bacterial diversity of a semiarid soil contaminated with different levels of formulated atrazine. Appl. Soil Ecol. 34:93-102.

38. Ruzo, L. O. 2006. Physical, chemical and environmental properties of selected chemical alternatives for the pre-plant use of methyl bromide as soil fumigant. Pest Manage. Sci. 62:99-113.

39. Saeed, I. A. M., Rouse, D. I., Harkin, J. M., and Smith, K. P. 1997. Effects of soil water content and soil temperature on efficacy of metam-sodium against Verticillium dahliae. Plant Dis. 81:773-776. 
40. Smelt, J. H., Crum, S. J. H., and Teunissen, W. 1989. Accelerated transformation of the fumigant methyl isothiocyanate in soil after repeated application of metam-sodium. J. Environ. Sci. Health B24:437455.

41. Smelt, J. H., and Leistra, M. 1974. Conversion of metham-sodium to methyl isothiocyanate and basic data on the behaviour of methyl isothiocyanate in soil. Pestic. Sci. 5:401-407.

42. Smelt, J. H., Teunissen, W., Crum, S. J. H., and Leistra, M. 1989. Accelerated 1,3-dichloropropene transformation in loamy soils. Neth. J. Agric. Sci. 37:173-183.

43. Smelt, J. H., van de Peppel Groen, A. E., van der Pas, L. J. T., and Dijksterhuis, A. 1996. Development and duration of accelerated degradation of nematicides in different soils. Soil Biol. Biochem. 12:17571765 .

44. Tal, A., Rubin, B., Katan, J., and Aharonson, N. 1989. Fate of ${ }^{14}$ C-EPTC in soil exhibiting accelerated degradation of carbamothioate herbicides and its control. Weed Sci. 37:434-439.

45. Triky-Dotan, S., Austerweil, M., Steiner, B., Peretz-Alon, I., Katan, J., and Gamliel, A. 2007. Generation and dissipation of methyl isothiocyanate in soils following metam sodium fumigation: Impact on Verticillium control and potato yield. Plant Dis. 91:497-503.

46. Triky-Dotan, S., Austerweil, M., Steiner, B., Peretz-Alon, I., Katan, J., and Gamliel, A. 2009. Accelerated degradation of metam-sodium in soil and consequences on root-disease management. Phytopathology 99:362368.

47. Valle, A., Boschin, G., Negri, M., Abbruscato, P., D’Agostina, A., and Zanardini, E. 2006. The microbial degradation of azimsulfuron and its effect on the soil bacterial community. J. Appl. Microbiol. 101:443-452.

48. Verhagen, C., Lebbink, G., and Bloem, J. 1996. Enhanced biodegradation of the nematicides 1,3-dichloropropene and methyl isothiocyanate in a variety of soils. Soil Biol. Biochem. 28:1753-1756.

49. Wang, D., and Yates, S. R. 1999. Spatial and temporal distributions of 1,3dichloropene in soil under drip and shank application and implications for pest control efficacy using concentration-time index. Pestic. Sci. 55:154160.

50. Warton, B., and Matthiessen, J. N. 2000. Enhanced biodegradation of metam sodium soil fumigant in Australia. Proc. BCPC Conf. Pests Dis. 4C-4:377-380

51. Warton, B., Matthiessen, J. N., and Roper, M. M. 2001. The soil organisms responsible for the enhanced biodegradation of metam sodium. Biol. Fertil. Soils 34:264-269.

52. Warton, B., Matthiessen, J. N., and Shackleton, M. A. 2003. Crossenhancement: Enhanced biodegradation of isothiocyanates in soils previously treated with metam sodium. Soil Biol. Biochem. 35:11231127.

53. Yarden, O., Aharonson, N., and Katan, J. 1987. Accelerated microbial degradation of methyl benzimidazol-2-ylcarbamate in soil and its control. Soil Biol. Biochem. 19:735-739.

54. Zhang, W., Spokas, K., and Wang, D. 2005. Degradation of methyl isothiocyanate and chloropicrin in forest nursery soils. J. Environ. Qual. 34:1566-1572.

55. Zheng, W., Yates, S. R., Papiernik, S. K., and Nunez, J. 2006. Conversion of metam sodium and emission of fumigant from soil columns. Atmos. Environ. 40:7046-7056. 